\title{
Penerapan pendekatan pembelajaran kontekstual untuk meningkatkan penguasaan konsep dasar listrik statis mahasiswa
}

\author{
Muhammad Minan Chusni \\ Program Studi Pendidikan Fisika, UIN Sunan Gunung Djati Bandung \\ Jalan A.H. Nasution No. I05 Cibiru Bandung \\ Surat-e: minan.chusni@uinsgd.ac.id
}

\begin{abstract}
Tujuan penelitian ini adalah untuk mengetahui pengaruh penerapan pendekatan pembelajaran kontekstual dalam meningkatkan penguasaan konsep dasar listrik statis mahasiswa. Penelitian ini menggunakan tiga kelas sampel yaitu dua kelas eksperimen dan satu kelas kontrol. Desain penelitian adalah random pretest-posttest comparison group design. Teknik pengumpulan data menggunakan pretes dan postes untuk mengetahui penguasaan konsep dasar listrik statis. Uji hipotesis menggunakan uji t untuk membandingkan penguasaan konsep dasar listrik statis kelas eksperimen (kelas A dan kelas D) dan kelas kontrol (kelas B), kemudian uji lanjut dengan pembandingan rerata (compare means) dan rata-rata absolute gain. Dari hasil penelitian diperoleh nilai thitung kelas A (4,298) dan thitung kelas D (4,6I3) > ttabel $(2,000)$, ditambah lagi dengan nilai Sig. 0,000 < 0,05 sehingga dapat disimpulkan bahwa pendekatan pembelajaran kontekstual secara signfikan memberikan perbedaan terhadap penguasaan konsep dasar listrik statis mahasiswa. Sedangkan dari uji compare means dan rata-rata gain ternormalisasi diperoleh kenaikan yang tinggi pada kelas eksperimen dibandingkan dengan kelas kontrol.
\end{abstract}

\begin{abstract}
The purpose of this study was to determine the effect of the application of contextual learning approach to improve the mastery of basic concepts of static electricity students. This study use three grade sample of two experimental class and the control class. The study design was randomized pretest-posttest comparison group design. Data collection technique used pretest and posttest to determine mastery of basic concepts of static electricity. Hypothesis testing using t-test to compare the mastery of basic concepts of static electricity experiment class (class $\mathrm{A}$ and class D) and the control class (class B), then a further test by comparing the mean (compare means) and average absolute gain. The results were obtained tcount class A (4.298) and $t_{\text {count }}$ class D (4.613)> table $(2.000)$, coupled with the Sig. $0.000<0.05$ so that it can be concluded that the approach of contextual learning exhibited significantly distinction of static electricity mastery of basic concepts students. While the means test and compare the average normalized gain obtained a very high increase in the experimental class compared with the control class.
\end{abstract}

Kata kunci: pembelajaran, kontekstual, listrik statis

\section{Pendahuluan}

Sejauh ini pendidikan kita masih didominasi oleh pandangan bahwa pengetahuan merupakan fakta-fakta yang harus dihafal. Kelas masih berfokus pada dosen sebagai sumber ilmu pengetahuan dan ceramah menjadi pilihan utama pembelajaran. Dosen mempunyai peran utama dalam proses pembelajaran. Mengingat peran yang sangat stategis tersebut, dosen harus mengupayakan adanya inovasi-inovasi untuk meningkatkan kualitas pembelajaran di kelas, baik itu pendekatan, model pembelajaran, media pembelajaran ataupun alat evaluasi hasil belajar yang tepat.

Menurut Jhonson, pembelajaran kontekstual membuat siswa memiliki kemampuan untuk menghubungkan konsep-konsep teoritis dengan konteks kehidupan keseharian untuk menemukan makna ${ }^{[\mathrm{I}]}$, teori tersebut didukung dengan hasil penelitian yang dilakukan oleh Mulyani, dan Miadi, bahwa dengan penerapan pembelajaran konteksual dapat meningkatkan penguasaan konsep mahasiswa dengan baik adalah pembelajaran kontekstual (CTL) $)^{[2],[3]}$. 
Pembelajaran kontekstual adalah konsep belajar yang diajarkan dengan situasi dunia nyata mahasiswa dan mendorong mahasiswa membuat hubungan antara pengetahuan yang dimilikinya dengan penerapannya dalam kehidupan sehari-hari, dengan melibatkan tujuh komponen utama pembelajaran efektif yakni: konstruktivisme, bertanya, menemukan, masyarakat belajar, pemodelan, refleksi, dan penilaian kinerja ${ }^{[4]}$.

Penguasaan konsep adalah proses pembangkitan makna dari sumber bervariasi, misalnya melalui pengamatan fenomena, membaca, mendengar, dan diskusi. Konsep mengandung informasi yang terorganisasi, misalnya objek, kejadian, gagasan, dan proses. Sedangkan keaktifan erat kaitannya dengan aktivitas. Menurut Dimyati bahwa keaktifan belajar ialah derajat/rentang keaktifan peserta didik pada pembelajaran ${ }^{[5]}$. Keaktifan dimaksudkan adalah kegiatan mahasiswa dalam pembelajaran yang diamati secara langsung oleh observer dan peneliti.

Dari hasil observasi dalam pembelajaran mahasiswa PGSD di Universitas Muhammadiyah Magelang ditemukan bahwa belum dioptimalkannya alat peraga dan media untuk pembelajaran konsep dasar IPA karena belum tersedianya sarana dan prasarana yang mendukung. Mahasiswa dalam pembelajarnnya juga belum mamanfaatkan lingkungan sekitar untuk mendukung pembelajaran konsep dasar IPA. Hal ini mengakibatkan mahasiswa kurang bisa mengkaitkan materi yang dipelajari dengan kenyataan di alam sekitar sehingga penguasaan konsep IPA-nya banyak yang masih kurang maksimal. Selain itu kemampuan mahasiswa dalam memecahkan masalah, berpikir kritis belum terasah sehingga penguasaan konsep dasar IPA dalam proses belajar masih rendah. Atas dasar alasan tersebut peneliti bermaksud untuk mengetahui penerapan pembelajaran kontekstual dalam meningkatkan penguasaan konsep dasar IPA khususnya materi listrik statis pada mahasiswa PGSD UMM Magelang.

\section{Kajian Pustaka}

Pembelajaran kontekstual atau disebut Contextual Teaching and Learning (CTL) pertama kali diusulkan oleh John Dewey yaitu suatu metodologi pengajaran yang dikaitkan dengan minat dan pengalaman dari peserta didik $^{[6]}$. Pembelajaran kontekstual adalah konsep belajar yang diajarkan dengan situasi dunia nyata mahasiswa dan mendorong mahasiswa membuat hubungan antara pengetahuan yang dimilikinya dengan penerapannya dalam kehidupan sehari-hari, dengan melibatkan tujuh komponen utama pembelajaran efektif yakni: konstruktivisme, bertanya, menemukan, masyarakat belajar, pemodelan, refleksi dan penilaian sebenarnya ${ }^{[4]}$.

Sebuah kelas dikatakan menggunakan pembelajaran kontekstual jika telah menerapkan ketujuh komponen tersebut diatas, yaitu jika filosofi belajarnya adalah konstruktivisme, selalu ada unsur bertanya, pengetahuan dan pengalaman diperoleh dari kegiatan menemukan, terbentuk masyarakat belajar, ada model yang ditiru (pemodelan) dan dilakukan penilaian otentik/sebenarnya ${ }^{[4]}$. Salah satu ciri fisik kelas dengan penerapan pembelajaran kontekstual adalah dinding kelas penuh dengan tempelan hasil karya mahasiswa. Dinding kelas penuh dengan gambar hasil karya mahasiswa, peta, artikel, foto tokoh, diagram, dan lain-lain. Setiap saat berubah. Bahkan lorong-lorong sekolah dapat dimanfaatkan. Akibatnya, kemanapun mahasiswa pergi dikepung oleh informasi. Ciri kedua, kelas dengan penerapan pembelajaran kontekstual adalah mahasiswa selalu ramai dan gembira dalam belajar. Kelas yang aktif bukan kelas yang sepi ${ }^{[4]}$.

Klausmeier dalam Dewi Padmo mendefinisikan konsep sebagai suatu konstruksi mental yang disimpulkan dengan suatu kata ${ }^{[7]}$. Konsep mengandung informasi yang terorganisasi, misalnya objek, kejadian, gagasan, dan proses. Pembelajaran pembentukan konsep dapat dilakukan melalui tiga tingkatan, yaitu tingkatan konkret dan identitas, tingkatan klasifikasi, dan tingkatan formal. Pemahaman konsep adalah proses pembangkitan makna dari sumber-sumber bervariasi, misalnya melalui pengamatan fenomena, membaca, mendengar, dan diskusi. Proses pemahaman melibatkan penyadapan informasi baru dan mengintegrasikannya ke dalam apa yang telah diketahui untuk mengonstruksi makna baru. Strategi pengonstruksian makna dapat dilakukan dengan pembelajaran kontruktivistik.

Listrik statis merupakan konsep IPA yang bersifat abstrak, khususnya perpindahan elektron yang menyebabkan suatu benda bermuatan. Elektron tidak bisa dilihat, hanya bisa dimodelkan. Listrik statis adalah muatan listrik yang berada pada setiap benda dalam keaddan diam, karena setiap benda tersusun dari atomatom $^{[8][9]}$. Dalam proses pembelajaran menggunakan pendekatan kontekstual bisa diperlihatkan interaksi benda bermuatan setelah digosok, misalnya kaca digosok dengan menggunakan kain wol. Gejala listrik statis, bagaimana sebuah benda bermuatan listrik netral, postif, atau negatif. Apabila dua benda digosok, maka akan terjadi pengurangan atau penambahan electron, misalnya dalam percobaan medan listrik dengan menggunakan palstik PVC uang digosok dengan wol kemudian didekatnkan dengan balon, akan mengalami tarik menarik yang menunjukkan adanya medan listrik disekitarnya. Hal sesuai dengan persamaan hukum Coulomb ${ }^{[9]}$ :

$$
F=k \frac{q_{1} q_{2}}{r^{2}}
$$

Keterangan: $F=$ gaya elektrostatis (newton), $q_{1}=$ besar muatan pertama (coulomb); $q_{2}=$ besar muatan kedua(coulomb); $r=$ jarak kedua muatan (meter).

Aplikasi dari listrik statis dalam pembelajaran konteksual yang berkaitan dengan perpindahan muatan 
listrik dan untuk mengetahui jenis dari muatan listrik, dapat dijelaskan pada materi pembuatan elektroskop sederhana. Prinsip kerja dari elektroskop adalah dengan pemberian muatan positif atau negative pada kepala elektroskop akan menghasilkan pengaruh yang sama, yaitu kedua keeping saling menjauh. Jika benda tidak bermuatan, kedua keeping tidak melakukan gaya elektrostatis dan tetap pada posisi menguncup ${ }^{[8]}$.

\section{Metode Penelitian/Eksperimen}

Penelitian ini menggunakan tiga kelas sebagai sampel secara cluster random sampling yaitu dua kelas eksperimen dan satu kelas kontrol dari populasi 5 kelas pada program studi PGSD Universitas Muhammadiyah Magelang semester 3 tahun 2013/20I4. Teknik pengumpulan data menggunakan metode pretes dan postes untuk mengetahui perbedaan penguasaan konsep dasar listrik statis. Rancangan desain penelitian adalah random pretest-posttest comparison group design ${ }^{[10]}$.

Tabel I. Desain Penelitian

\begin{tabular}{cccc}
\hline Group & Pretest & Treatment & Posttest \\
\hline Kelas Kontrol $(\mathrm{KK})$ & $\mathrm{X}$ & $\mathrm{Xa}$ & $\mathrm{Y}$ \\
Kelas Treatment $(\mathrm{KT})$ & $\mathrm{X}$ & $\mathrm{Xb}$ & $\mathrm{Y}$ \\
\hline
\end{tabular}

Keterangan : KK adalah kelas kontrol yang menerapkan pembelajaran listrik statis dengan menggunakan pembelajaran konvensional, KT adalah kelas eksperimen yang menerapkan pembelajaran listrik statis dengan menggunakan pendekatan kontekstual.

Uji hipotesis menggunakan uji-t dengan program komputasi SPSS untuk mengetahui perbedaan penguasaan konsep dasar listrik statis antara kelas eksperimen dan kelas kontrol. Kemudian dilakukan uji lanjut pembandingan rerata (compare means) dan untuk mengetahui efektivitas pembelajaran terhadap peningkatan prestasi belajar dapat dilakukan melalui analisis terhadap nilai rata-rata gain ternormalisasi. Kriteria skor gain yang dinormalisasi diadopsi dari Hake dapat dilihat pada persamaan berikut ${ }^{[1]}$.

$$
<g>=\frac{\%<S_{f}>-\%<S_{i}>}{100-\%<S_{i}>}
$$

Keterangan : $\langle g\rangle=$ rata-rata gain ternormalisasi, $\left\langle S_{f}\right\rangle=$ skor postes, dan $\langle S i>=$ skor pretes.

Adapun interpretasid dari nilai rata-rata gain ternormalisai ditunjukkan oleh tabel 2 berikut.
Tabel 2. Interpretasi Nilai Gain Ternormalisasi

\begin{tabular}{cc}
\hline Nilai $<\mathrm{g}>$ & Klasifikasi \\
\hline$(<\mathrm{g}>) \geq 0,7$ & Tinggi \\
$0,3 \leq(<\mathrm{g}>)<0,7$ & Sedang \\
$(<\mathrm{g}>)<0,3$ & Rendah \\
\hline
\end{tabular}

Instrumen penelitian yang digunakan dalam penelitian ini terdiri dari lembar kegiatan mahasiswa (LKM) untuk memfasilitasi pembelajran konteksual, lembar observasi pembelajaran kontekstual untuk penilaian proses pembelajaran secara langsung, dan soal pretes dan postes yang disusun dalam bentuk pilihan ganda dan esay untuk mengetahui penguasaan konsep dasar mahasiswa pada materi listrik statis.

\section{Hasil Penelitian dan Pembahasan}

Data pretes konsep dasar listrik statis mahasiswa merupakan data awal kemampuan penguasaan konsep mahasiswa sebelum dilakukan pembelajaran dengan pendekatan kontekstual untuk kelas A dan D serta pembelajaran konvensional pada kelas $\mathrm{C}$ sedangkan postes merupakan hasil akhir kemampuan penguasaan konsep setelah diberikan pembelajaran materi listrik statis. Deskripsi data nilai pretes dan postes mahasiswa disajikan pada tabel 3 berikut.

Tabel 3. Data Pretes dan Postes Mahasiswa Kelas Kontekstual dan Konvensional

\begin{tabular}{|c|c|c|c|c|}
\hline $\begin{array}{c}\text { Pendek } \\
\text { atan }\end{array}$ & Kelas & $\begin{array}{l}\text { Distribusi } \\
\text { Frekuensi }\end{array}$ & $\begin{array}{l}\text { Nilai } \\
\text { Pretes }\end{array}$ & $\begin{array}{l}\text { Nilai } \\
\text { Postes }\end{array}$ \\
\hline \multirow{8}{*}{$\begin{array}{c}\text { Pembel } \\
\text { ajaran } \\
\text { Kontek } \\
\text { stual }\end{array}$} & \multirow{4}{*}{ A } & Mean & $44,8 \mathrm{I}$ & 73,90 \\
\hline & & Median & 42,86 & 80,00 \\
\hline & & Minimum & $\mathrm{I} 4,29$ & 31,43 \\
\hline & & Maksimum & 74,29 & $97, \mathrm{I} 4$ \\
\hline & \multirow{4}{*}{$\mathrm{D}$} & Mean & 41,39 & 70,04 \\
\hline & & Median & 40,00 & 71,43 \\
\hline & & Minimum & $\mathrm{I7}, \mathrm{I} 4$ & $37, \mathrm{I} 4$ \\
\hline & & Maksimum & 62,86 & 91,43 \\
\hline \multirow{4}{*}{$\begin{array}{c}\text { Pembel } \\
\text { ajaran } \\
\text { Konven } \\
\text { sional }\end{array}$} & \multirow{4}{*}{ C } & Mean & 39,13 & 54,20 \\
\hline & & Median & 40,00 & $5 \mathrm{I}, 43$ \\
\hline & & Minimum & 17,14 & 34,29 \\
\hline & & Maksimum & 77,14 & 91,43 \\
\hline
\end{tabular}

Dari tabel 3 terlihat bahwa nilai rata-rata hasil postes mahasiswa mengalami peningkatan dibandingkan nilai rata-rata pada pretes sebelum dilakukan pembelajaran. Nilai minimum dan maksimum dari masing-masing kelas menunjukkan peningkatan apabila dibandingkan hasil pretes. Hal ini berarti bahwa pembelajaran yang diberikan baik menggunakan pendekatan kontekstual maupun konvensional memberikan peningkatan penguasaan 
konsep pada mahasiswa. Peningkatan tersebut yang akan dianalisis lebih lanjut untuk mengetahui efektivitas pembelajaran yang memberikan pengaruh lebih signifikan pada penguasaan konsep dasar listrik statis mahasiswa.

Analisis pembandingan dilakukan terhadap peningkatan nilai rata-rata gain ternormalisasi yang dicapai mahasiswa $^{[11]}$. Hasil uji $t$ terhadap pengujian hipotesis menggunakan SPSS dirangkum dalam tabel 4 berikut.

Tabel 4. Data Hasil Uji t

\begin{tabular}{|c|c|c|c|c|c|}
\hline \multirow[b]{2}{*}{$\mathrm{Uji}_{\mathrm{t}}$} & \multirow[b]{2}{*}{ Variansi } & \multirow[b]{2}{*}{$\mathrm{t}$} & \multirow[b]{2}{*}{ Sig. } & \multicolumn{2}{|c|}{ Kesimpulan } \\
\hline & & & & $\begin{array}{c}\text { Hipo } \\
\text { tesis }\end{array}$ & Ket. \\
\hline $\begin{array}{l}\text { Gain } \\
\text { kelas }\end{array}$ & $\begin{array}{l}\text { Diasumsikan } \\
\text { variansi sama }\end{array}$ & 4,298 & $\begin{array}{l}0,0 \\
00\end{array}$ & \multirow{2}{*}{$\begin{array}{l}\text { Ho } \\
\text { ditola } \\
\mathrm{k}\end{array}$} & \multirow{2}{*}{$\begin{array}{l}\text { Ada } \\
\text { per } \\
\text { bed } \\
\text { aan }\end{array}$} \\
\hline $\begin{array}{l}\text { A } \\
\text { terha } \\
\text { dap C }\end{array}$ & $\begin{array}{l}\text { Diasumsikan } \\
\text { variansi } \\
\text { taksama }\end{array}$ & 4,486 & $\begin{array}{l}0,0 \\
00\end{array}$ & & \\
\hline $\begin{array}{l}\text { Gain } \\
\text { kelas }\end{array}$ & $\begin{array}{l}\text { Diasumsikan } \\
\text { variansi sama }\end{array}$ & $4,6 \mathrm{I} 3$ & $\begin{array}{l}0,0 \\
00 \\
\end{array}$ & \multirow{2}{*}{$\begin{array}{l}\text { Ho } \\
\text { ditol } \\
\text { ak }\end{array}$} & \multirow{2}{*}{$\begin{array}{l}\text { Ada } \\
\text { per } \\
\text { bed } \\
\text { aan }\end{array}$} \\
\hline $\begin{array}{l}\text { D } \\
\text { terha } \\
\text { dap C }\end{array}$ & $\begin{array}{l}\text { Diasumsikan } \\
\text { variansi } \\
\text { taksama }\end{array}$ & 4,624 & $\begin{array}{l}0,0 \\
00\end{array}$ & & \\
\hline
\end{tabular}

Dari tabel 4 terlihat bahwa hasil uji hipotesis yang dilakukan diperoleh nilai thitung kelas A (4,298) dan thitung kelas D $(4,6 \mathrm{I3})>$ ttabel $(2,000)$, ditambah lagi dengan nilai Sig. $0,000<0,05$ sehingga dapat disimpulkan bahwa pendekatan pembelajaran kontekstual secara signfikan memberikan perbedaan terhadap penguasaan konsep dasar listrik statis mahasiswa dibandingkan dengan kelas konvensional.

Tahap selanjutnya dilakukan uji Compare Means untuk mengetahui mana yang lebih tinggi nilai rata-ratany. Adapun hasil perhitungannya disajikan dalam tabel 5 berikut.

Tabel 5. Data Nilai Compare Means Kelas Kontekstual dan Konvensional

\begin{tabular}{ccccc}
\hline Gain & Kelas & N & Rerata & $\begin{array}{c}\text { Std. } \\
\text { Deviasi }\end{array}$ \\
\hline $\begin{array}{c}\text { Gain kelas A } \\
\text { terhadap C }\end{array}$ & $\mathrm{A}$ & 44 & 29,0907 & $\mathrm{I} 5,797$ \\
\cline { 2 - 5 } Gain kelas D & 33 & $\mathrm{I} 5,0658$ & $\mathrm{I} 1,633$ \\
\cline { 2 - 5 } terhadap C & $\mathrm{C}$ & 33 & $28,653 \mathrm{I}$ & $\mathrm{I} 2,5967$ \\
\hline
\end{tabular}

Dari hasil uji lanjut Compare Means yang dirangkum pada tabel 5, dapat diketahui perbandingan rerata dari masing-masing kelas yang mendapat perlakuan pembelajaran yang berbeda. Kelas yang diberikan model pembelajaran kontekstual yaitu kelas A dan D memiliki rerata peningkatan nilai sebesar 29,0907 dan 28, 653I lebih tinggi daripada rerata kelas yang diberikan pembelajaran konvensional $\mathrm{C}$ memiliki rerata peningkatan nilai 15,0658. Adapun perhitungan nilai rata-rata gain ternormalisasi dari kelas eksperimen dan kelas kontrol, ditunjukkan pada tabel 6 berikut.

Tabel 6. Data Nilai Rata-Rata Gain Ternormalisasi

\begin{tabular}{ccccc} 
Kelas & & Mean Pretes & Mean Postes & $\langle\mathbf{g}\rangle$ \\
\hline \multirow{2}{*}{ Eksperimen } & A & $44,8 \mathrm{I}$ & 73,90 & 0,53 \\
\cline { 2 - 5 } & D & 41,39 & 70,04 & 0,49 \\
\hline Kontrol & C & 39,13 & 54,20 & 0,25 \\
\hline
\end{tabular}

Dari tabel 6 terlihat bahwa nilai rata-rata gain ternormalisasi pada kelas eksperiman untuk kelas A sebesar 0,53 dan kelas B sebesar 0,49, keduanya tergolong pada kategori pengingkatan yang sedang. Sedangkan pada kelas kontrol diperoleh angka sebesar 0,25 yang tergolaong peningkatan rendah ${ }^{[\mathrm{II}]}$.

Pada pembelajan ini mengandung tujuh komponen utama pembelajaran kontekstual yakni konstruktivisme, bertanya, menemukan, masyarakat belajar, pemodelan, refleksi dan penilaian otentik (4). Melalui pembelajaran listrik statis kontekstual yang dilakukan, mahasiswa dapat mengkonstruksi sendiri pengalaman belajar mereka secara langsung, menganalisis dan menemukan pemahaman konsep yang baru. Sebagai contoh, mahasiswa mempelajari adanya gaya tarik menarik antara benda bermuatan tak sejenis dan tolak menolak antara benda bermuatan sejenis. Mahasiswa mengalami langsung bagaimana membedakan dan membuat suatu bahan memiliki muatan yang sama atau berbeda kemudian mengamati langsung respon yang terjadi. Dengan demikian, mahasiswa telah mengalami komponen konstruktivisme, bertanya dan menemukan dalam proses pembelajaran listrik statis.

Selanjutnya ketika mahasiswa mengetahui adanya fenomena yang sama atau hampir sama dalam kehidupan sehari-hari maka mereka dapat mengaitkan pengalaman belajar di kelas ke kehidupan sehari-hari sehingga dapat terbentuklah adanya pemodelan, misalnya pada ssat mahasiswa mengamati adanya halilintar yang menyambar gedung yang dilengkapi penangkal petir sehingga aliran muatan listrik mengalir ke bumi dan tidak menyebabkan kerusakan pada gedung tersebut.

Komponen selanjutnya masyarakat belajar. Masyarakat belajar terjadi ketika proses komunikasi dua arah yaitu mendapatkan dan memberikan informasi. Setelah mahasiswa mendapatkan dan mengkonstruksi informasi dari pengalaman belajarnya, mereka dituntut dapat mengkomunikasikan melalui lembar kerja mahasiswa (LKM), mempresentasikan hasil pengamatan di depan kelas agar mendapat tanggapan dari kelompok lain dan 
keluaran akhir pemebelajaran berupa laporan hasil kegiatan yang disusun mahasiswa secara berkelompok.

Komponen refleksi merupakan respon terhadap kejadian, aktivitas atau pengetahuan baru diterima mahasiswa yang menjadi revisi ataupun pengayaan dari pengetahuan sebelumnya. Materi yang digunakan dalam penelitian ini adalah listrik statis yang dasar-dasarnya pernah dipelajari di tingkat Sekolah Dasar, Sekolah Menengah Pertama (SMP), Sekolah Menengah Atas (SMA) sehingga diharapkan dengan pembelajaran yang dilakukan dapat menjadi revisi dari pengetahuan sebelumnya yang mungkin kurang tepat atau dapat menjadi pengayaan dengan menambah dan memperdalam pengetahuan dibandingkan sebelumnya.

Komponen terakhir dari proses pembelajaran kontekstual yaitu penilaian otentik yang merupakan proses pengumpulan data gambaran perkembangan proses belajar dari mahasiwa dengan menggunakan lembar observasi kegiatan mahasiswa saat melakukan pembelajaran meliputi ketepatan saat merangkai alat, melakukan prosedur percobaan, kemampuan mengatasi masalah dan kerjasama tim saat pembelajaran.

\section{Kesimpulan}

P Berdasarkan tujuan penelitian, kajian teori, dan pembahasan hasil analisis yang telah diuraikan, maka pada penelitian ini dapat dihasilkan kesimpulan bahwa dari hasil uji t terhadap nilai penguasaan konsep dasar listrik statis mahasiswa antara kelas eksperimen yang menggunakan pembelajaran kontekstual dibandingkan kelas kontrol yang menggunakan pembelajaran konvensional menunjukkan bahwa terdapat perbedaan yang signifikan. Kemudian dilanjutkan uji compare means dan rata-rata gain ternormalisasi menunjukkan kelas yang memperoleh pembelajaran kontekstual memiliki peningkatan nilai lebih tinggi dari pada kelas konvensional.

\section{Ucapan Terimakasih}

Ucapan terima kasih merupakan bentuk apresiasi adanya kontribusi dari perorangan maupun lembaga yang tidak bisa masuk sebagai penulis. Misalnya pemberi dana penelitian yang terkait dengan publikasi ini.

\section{Kepustakaan}

[I] Johnson, Elaine B. Contextual Teaching \& Learning Menjadikan Kegiatan Belajar Mengajar Mengasyikkan dan Bermakna. Bandung : MLC, 2007.

[2] Mulyani. Pengaruh Penerapan Pembelajaran Kontekstual Terhadap Penguasaan Konsep Bahan Kimia dalam Kehidupan Sehari-Hari dan Keterampilan Berpikir Kritis Siswa Kelas VIII SMP N 4 Metro. 2, Lampung : BIOEDUKASI, 20I3, Vol. 4.
[3] Miadi, Okta. Penggunaan Pendekatan Teaching and Learning (CTL) Untuk Meningkatkan Penguasaan Konsep Energi dan Usaha. Jakarta : UIN Syarif Hidayatullah, 2014.

[4] Nurhadi. Pendekatan Kontekstual. Jakarta : Depdiknas, 2002.

[5] Dimyati and Mudjiono. Belajar dan Pembelajaran. Jakarta: Rineka Cipta, 2009.

[6] Trianto. Model-Model Pembelajaran Inovatif Berorientasi Konstruktivistik. Jakarta : Prestasi Pustaka, 2007.

[7] Padmo, Dewi and dkk. Teknologi Pembelajaran: Peningkatan Kualitas Belajar melalui Teknologi Pembelajaran. Jakarta : Pusat Teknologi dan Informasi Pendidikan, 2004.

[8] Abdullah, Mikrajuddin. IPA Fisika SMP dan MTS Jilid 3. Jakarta : ESIS, 2007.

[9] Tipler, Paul A. Physics for Scientist and Engineers, Third Edition. Jakarta : Erlangga, 1998.

[10] Sugiyono. Metode Penelitian Administrasi. Bandung: Alfabeta, 2002.

[II] Hake, Richard R. Interactive Engagement Methodes In Introductory Mechanics Courses. Bloomingtoon: Indiana University, 1999. 
Penerapan pendekatan pembelajaran kontekstual untuk meningkatkan penguasaan konsep dasar listrik statis mahasiswa 